\title{
PENGARUH KEPERCAYAAN MEREK TERHADAP LOYALITAS PELANGGAN MEMBELI SHAMPO MEREK PANTENE (Studi Pada Mahasiswi Fakultas Ekonomi Universitas Tadulako Palu)
}

\author{
ELOK CAHYANINGTYAS \\ H. CHALIL \\ PONIRIN \\ Jurusan Manajemen, Fakultas Ekonomi, Universitas Tadulako \\ Email: seventyjenery@yahoo.co.id
}

\begin{abstract}
The aim of this research is to determine simultaneous and partial influence of trust brand on the loyalty of student of the Faculty of Economics, Tadulako University, Palu to buy Pantene Shampoo. Sampling method in this research is purposive sampling; with a total sample of 96 respondents. The results of hypothesis testing using $F$-test show that the three independent variables that are brand trust $(X)$ consisting of brand characteristics (X1), the characteristics of the company (X2) and the characteristics of customers with the brand (X3) simultaneously have positive and significant influence on the dependent variable customer loyalty $(Y)$ with sig-F of $0.000<0.05$. Furthermore, the brand characteristic variable (X1) with sig 0,001, characteristic of the company (X2) with sig of 0.001 , and characteristics of customers to the brand value of sig $0.004<0.05$, which shows partial influence on customer loyalty variable $(Y) . R^{2}$ values of 0.645 and brand belief variable $(X)$ simultaneously influence customer loyalty $(Y)$ of $64.5 \%$, while the remaining $35.5 \%$ is influenced by other factors that are not examined.
\end{abstract}

Keywords: brand characteristics, company characteristics customers, characteristics with brand, and customer loyalty.

\begin{abstract}
Abstrak
Penelitian ini bertujuan untuk mengetahui pengaruh secara simultan dan parsial dari kepercayaan merek terhadap loyalitas mahasiswi Fakultas Ekonomi Universitas Tadulako Palu. Teknik penarikan sampel dalam penelitian ini adalah purposive sampling, dengan jumlah sampel sebanyak 96 responden. Hasil pengujian hipotesis menggunakan uji $\mathrm{F}$ bahwa ketiga variabel independen kepercayaan merek (X) yang terdiri dari karakteristik merek (X1), karakteristik perusahaan (X2) dan karakteristik pelanggan dengan merek (X3) terbukti secara simultan berpengaruh positif dan signifikan terhadap variabel dependen loyalitas pelanggan (Y) dengan nilai sig-F sebesar 0,000<0,05. Selanjutnya variabel karakteristik merek (X1) dengan nilai sig sebesar 0,001, karakteritik perusahaan (X2) dengan nilai sig sebesar 0,001 dan karakteristik pelanggan dengan merek nilai sig sebesar 0,004 $<0.05$ yang berarti secara parsial berpengaruh terhadap variable loyalitas pelanggan (Y). Nilai $\mathrm{R}_{2}$ sebesar 0,645 dengan demikian variabel kepercayaan merek (X) yang diteliti secara serempak memberikan pengaruh terhadap variabel loyalitas pelanggan $(\mathrm{Y})$ sebesar $64,5 \%$ sementara sisanya 35,5\% dipengaruhi oleh faktor lain yang tidak diteliti.
\end{abstract}

Kata Kunci: Karakteristik Merek, Karakteristik Perusahaan, Karakteristik Pelanggan Dengan Merek, Loyalitas Pelanggan.

\section{PENDAHULUAN}

Persaingan bisnis produk shampo di Indonesia mempunyai persaingan pasar yang pesat, hal ini ditunjukan dengan semakin gencarnya penayangan iklan di media televisi dan media sosial. Terdapat sepuluh merek shampo yang dikenal secara luas di pasar Indonesia yaitu Pantene, Clear, Sunslik, Lifebouy, Dove, Rejoice, Zink, Emeron, Hend \& Shoulder, dan Tresemme. Produk shampo dengan merek tertentu mempunyai pangsa pasar dan segmen pasar yang konsumennya fanatik, karena adanya kecocokan kualitas shampo dengan karakteristik rambut yang dimilikinya. Sumarwan (2004:137) menyatakan bahwa kepercayaan terhadap merek adalah kemauan pelanggan mempercayai merek dengan segala risikonya, karena adanya harapan yang dijanjikan oleh merek dalam memberikan hasil yang positif bagi pelanggan. 
Salah satu produk shampo yang dikenal secara luas khususnya pada kaum wanita di pasar Indonesia saat ini adalah produk shampo merek Pantene. Walaupun saat ini ada sejumlah merek shampo yang terkenal lainnya dan ikut bersaing di segmen pasar yang sama yaitu diantaranya Sunslik, Dove, Rejoice, Zink, Emeron, dan Tresemme. Produk shampo Pantene terus melakukan inovasi sesuai perubahan zaman yang mengikuti selera dan kebutuhuan rambut khususnya wanita. Produk shampo Pantene diproduksi oleh perusahaan P\&G (Procter \& Gamble) yang berasal dari USA yang didirikan pada tahun 1837. Pantene selalu menyediakan produk-produk yang memberi pelanggan manfaat rambut sehat. Hal ini memberikan kepercayaan diri kepada pelanggan sehingga pelanggan merasa puas, untuk memungkinkan perawatan rambut yang berkilau.

Produk shampo Pantene tidak hanya dikenal di kalangan wanita dewasa dan wanita karir, di kalangan wanita muda khususnya mahasiswi juga merupakan kebutuhan untuk menjaga agar rambut mereka tetap bersih dan sehat, guna mendapatkan penampilan maksimal. Saat ini produk shampo Pantene telah menjadi Top Leader kategori Shampo dalam penilaian Top Brand Index tahun 2013 2016 yang selalu mempertahankan peringkat dari tahun 2013 - 2016. Hal ini menunjukan bahwa produk shampo Pantene sebagai market leader dapat dilihat dalam Tabel. 1 berikut ini:

Tabel 1 Top Brand Index Shampo

\begin{tabular}{|c|l|l|l|l|l|l|l|l|l|}
\hline \multirow{2}{*}{ NO } & \multicolumn{2}{|c|}{$\mathbf{2 0 1 3}$} & \multicolumn{2}{c|}{2014} & \multicolumn{2}{c|}{ 2015 } & \multicolumn{2}{c|}{ 201 6 } & \\
\cline { 2 - 9 } & \multicolumn{1}{|c|}{ Merek } & TBI & Merek & \multicolumn{1}{|c|}{ TBI } & \multicolumn{1}{|c|}{ Merek } & \multicolumn{1}{|c|}{ TBI } & \multicolumn{1}{|c|}{ Merek } & TBI & \\
\hline 1 & Pantene & $27.3 \%$ & Pantene & $25.1 \%$ & Clear & $22.1 \%$ & Pantene & $22.0 \%$ & TOP \\
\hline 2 & Clear & $22.1 \%$ & Clear & $22.5 \%$ & Pantene & $21.4 \%$ & Clear & $18.2 \%$ & TOP \\
\hline 3 & Sunsilk & $18.5 \%$ & Sunsilk & $16.5 \%$ & Sunsilk & $18.2 \%$ & Sunsilk & $21.9 \%$ & TOP \\
\hline 4 & Lifebuoy & $11.4 \%$ & Lifebuoy & $10.9 \%$ & Lifebuoy & $9.7 \%$ & Lifebuoy & $13.1 \%$ & \\
\hline 5 & Dove & $5.5 \%$ & Dove & $6.1 \%$ & Dove & $8.4 \%$ & Dove & $8.2 \%$ & \\
\hline 6 & Rejoice & $5.0 \%$ & Rejoice & $4.8 \%$ & Rejoice & $5.6 \%$ & Rejoice & $4.8 \%$ & \\
\hline 7 & Zinc & $3.7 \%$ & Zinc & $4.6 \%$ & Zinc & $4.3 \%$ & Zinc & $4.2 \%$ & \\
\hline
\end{tabular}

Sumber : www.topbrand-award.com (survei tahun 2013 - 2016)

Pada Tabel 1 di atas menunjukkan bahwa peningkatan yang terjadi pada produk shampo Pantene tahun 2015-2016 menjadi bukti bahwa Pantene mampu bertahan dalam persaingan guna mengembangkan produknya dalam posisi market leader. Meskipun pada tahun 2015 mengalami penurunan dengan berada di peringkat kedua dan mengalami peningkatan kembali pada tahun 2016 di peringkat pertama dalam kategori Top Brand. Berdasarkan latar belakang tersebut maka peneliti tertarik untuk mengambil judul "Pengaruh Kepercayaan Merek Terhadap Loyalitas Pelanggan Membeli Shampo Merek Pantene (Studi Pada Mahasiswi Fakultas Ekonomi Universitas Tadulako)"

\section{Rumusan Masalah}

Berdasarkan latar belakang yang di uraikan di atas maka peneliti dapat merumuskan beberapa pokok permasalahan dalam penelitian ini sebagai berikut :

1. Apakah kepercayaan merek yang terdiri dari karakteristik merek, karakteristik perusahaan dan karakteristik pelanggan dengan merek secara simultan berpengaruh positif dan signifikan terhadap loyalitas mahasiswi Fakultas Ekonomi Universitas Tadulako Palu membeli produk shampo Pantene?

2. Apakah variabel karakteristik merek secara parsial berpengaruh positif dan signifikan terhadap loyalitas mahasiswi Fakultas Ekonomi Universitas Tadulako Palu membeli produk shampo Pantene?

3. Apakah variabel karakteristik perusahaan secara parsial berpengaruh positif dan signifikan terhadap loyalitas mahasiswi Fakultas Ekonomi Universitas Tadulako Palu membeli produk shampo Pantene?

4. Apakah variabel karakteristik pelanggan dengan merek secara parsial berpengaruh positif dan signifikan terhadap loyalitas mahasiswi Fakultas Ekonomi Universitas Tadulako Palu membeli produk shampo Pantene? 


\section{Tujuan Penelitian}

Tujuan penelitian merupakan sebuah pedoman pada setiap penelitian untuk menjawab dari permasalahan penelitian yang dirumuskan. Maka dari perumusan masalah di atas tujuan dari penelitian ini adalah :

1. Untuk mengetahui pengaruh secara silmutan kepercayaan merek yang terdiri dari karakteristik merek, karakteristik perusahaan dan karakteristik pelanggan dengan merek terhadap loyalitas mahasiswi Fakultas Ekonomi Universitas Tadulako Palu membeli produk shampo Pantene.

2. Untuk mengetahui pengaruh secara parsial karakteristik merek terhadap loyalitas mahasiswi Fakultas Ekonomi Universitas Tadulako Palu membeli produk shampo Pantene.

3. Untuk mengetahui pengaruh secara parsial karakteristik perusahaan terhadap loyalitas mahasiswi Fakultas Ekonomi Universitas Tadulako Palu membeli produk shampo Pantene.

4. Untuk mengetahui pengaruh secara parsial karakteristik pelanggan dengan merek terhadap loyalitas mahasiswi Fakultas Ekonomi Universitas Tadulako Palu membeli produk shampo Pantene.

\section{KAJIAN LITERATUR DAN PENGEMBANGAN HIPOTESIS Pengertian Pemasaran}

American Marketing Association (AMA) (dalam Adisaputro 2010:4) mendenifisikan pemasaran adalah suatu fungsi organisasi dan serangkaian proses untuk menciptakan, mengomunikasikan, dan memberi nilai pada pelanggan dan untuk menggelola hubungan pelanggan dengan cara yang menguntungkan organisasi dan pemangku kepentinganya.

\section{Bauran Pemasaran (Marketing Mix)}

Sumarni dan Soeprihanto (2010:23) berpendapat bahwa bauran pemasaran (marketing mix) adalah kombinasi dari variabel atau kegiatan yang merupakan inti dari sistem pemasaran yaitu produk, harga, promosi, dan distribusi menurut pendapat. sedangkan Menurut Candra (2008:73) bauran pemasaran merupakan sekelompok variabel yang terdiri dari produk, harga, promosi, dan distribusi atau lokasi yang dapat dilaksanakan perusahaan untuk mempengaruhi permintaan akan produknya. Bauran pemasaran terdapat 4 variabel yang di kenal dengan istilah 4P yang berkaitan antara satu dengan yang lain. Yaitu: Produk (product), Harga (Price), Distribusi (place), dan Promosi (Promotion).

\section{Perilaku Konsumen}

Menurut Sumarwan (2004:5) menyatakan bahwa perilaku konsumen adalah semua kegiatan, tindakan, serta proses psikologis yang mendorong tindakan tersebut pada saat sebelum membeli, ketika membeli, menggunakan, menghabiskan produk dan jasa setelah melakukan hal-hal di atas atau kegiatan mengevaluasi.

\section{Pengertian Merek}

Simamora (2007:157) mendefinisikan merek adalah segala sesuatu yang mengidentifikasikan barang atau jasa penjual dan membedakannya dari barang dan jasa lainnya. Merek dapat berupa sebuah kata, huruf-huruf, sekelompok kata, simbol, desain, atau beberapa kombinasi.

\section{Kepercayaan merek}

Tjiptono (2008:32) berpendapat bahwa kepercayaan pada merek (trust in a brain) sebagai kesediaan atau kemauan konsumen untuk mempercayai atau mengandalkan merek dalam situasi segala resikonya karena ada harapan bahwa merek bersangkutan akan memberikan hasil positif bagi konsumen.

\section{Karakteristik merek}

Lau dan Lee (1999:52) berpendapat bahwa Karakteristik merek (Brand characteristic) mempunyai peran yang sangat penting dalam menentukan pengambilan keputusan konsumen untuk mempercayai suatu merek. Karakteristik merek memainkan berperan dalam menentukan apakah pelanggan memutuskan untuk percaya pada suatu merek.

\section{Karakteristik Perusahaan}

Menurut Riana (2012:26) karakteristik perusahaan juga dapat mempengaruhi tingkat kepercayaan pelanggan terhadap sebuah merek. Pengetahuan pelanggan tentang perusahaan yang ada 
di balik merek suatu produk merupakan dasar awal pemahaman pelanggan terhadap merek suatu produk.

\section{Karakteristik Pelanggan dan Merek}

Menurut Riana (2012:31) karakteristik pelanggan dengan merek merupakan dua kelompok yang saling mempengaruhi. Sehingga dapat mempengaruhi kepercayaan pelanggan terhadap merek. Oleh sebab itu, karakteristik pelanggan dengan merek berperan penting dalam mempengaruhi pelanggan untuk percaya terhadap merek produk tertentu.

\section{Kepuasan Konsumen}

Menurut Kotler dan Keller (2009:139) kepuasan (satisfaction) adalah perasaan senang atau kecewa seseorang yang timbul karena membandingkan kinerja yang dipresepsikan produk terhadap ekspentasi mereka. Penilaiaan pelanggan atas kinerja produk tergantung pada banyak faktor, terutama hubungan jenis loyalitas yang dimiliki oleh konsumen dengan sebuah merek.

\section{Loyalitas Pelanggan}

Surya dan Setiyaningrum (2009:27) menyatakan bahwa loyalitas pelanggan sebagai kekuatan hubungan antara sikap relatif individu terhadap suatu kesatuan (merek, jasa, toko, atau pemasok) dan pembelian ulang. Loyalitas pelanggan menekankan pada runtutan pembelian yang dilakukan konsumen seperti proporsi dan probabilitas pembelian.

\section{Hubungan antara Kepercayaan Merek dengan Loyalitas Pelanggan}

Loyalitas pelanggan menunjukan pada kesetiaan pelanggan pada objek tertentu seperti merek, produk, jasa atau toko tertentu. Delgado (2003:27), menyatakan bahwa kepercayaan pelanggan adalah penggerak utama loyalitas, karena loyalitas menciptakan hubungan pertukaran yang bernilai tinggi. Perilaku keterhubungan yang terjadi antara perusahaan dan konsumen banyak ditentukan oleh kepercayaan dan komitmen. Kepercayaan mempunyai hubungan yang positif dengan niat membeli ulang yang disebut dengan loyalitas pelanggan. Ketika pelanggan percaya terhadap suatu merek, dan memperlihatkan keinginannya untuk bergantung pada merek tersebut, maka pelanggan tersebut akan menunjukan maksud pembelian yang positif pada merek tersebut.

\section{Kerangka Pemikiran}

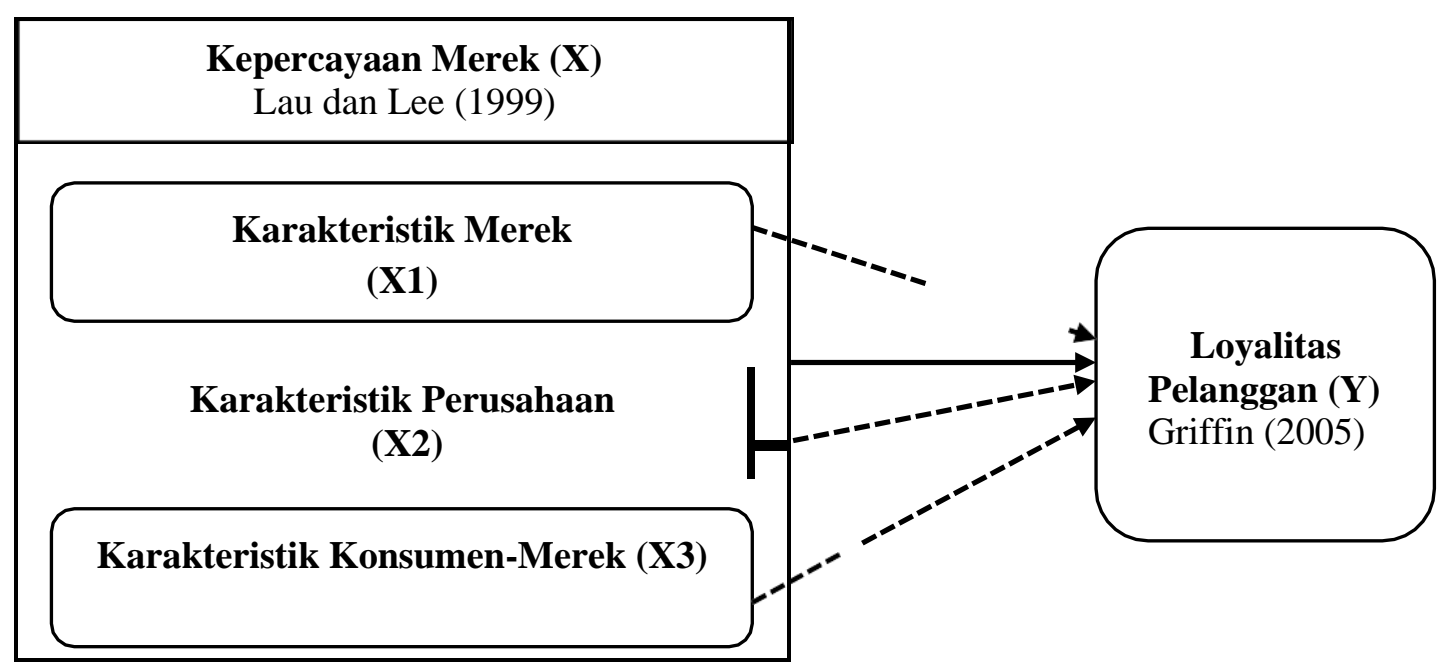

Sumber: Riana (2012:29)

\section{Gambar 1 Kerangka Pemikiran Penelitian}

Ket :

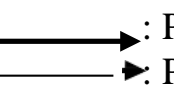

Pengaruh simultan (serempak)

Pengaruh parsial (Pengaruh masing-masing variabel bebas)

\section{Hipotesis}

Berdasarkan rumusan masalah dan tinjauan pustaka yang telah diuraikan, maka dapat ditentukan hipotesis penelitian sebagai berikut : 
1. Kepercayaan merek yang terdiri dari karakteristik merek, karakteristik perusahaan, dan karakteristik pelanggan dengan merek secara simultan berpengaruh positif dan signifikan terhadap loyalitas mahasiswi Fakultas Ekonomi Universitas Tadulako Palu membeli produk shampo Pantene.

2. Variabel Karakteristik merek secara parsial berpengaruh positif dan signifikan terhadap loyalitas mahasiswi Fakultas Ekonomi Universitas Tadulako Palu membeli produk shampo Pantene

3. Variabel karakteristik perusahaan secara parsial berpengaruh positif dan signifikan terhadap loyalitas mahasiswi Fakultas Ekonomi Universitas Tadulako Palu membeli produk shampo Pantene.

4. Variabel karakteristik pelanggan dengan merek secara parsial berpengaruh positif dan signifikan terhadap loyalitas mahasiswi Fakultas Ekonomi Universitas Tadulako Palu membeli produk shampo Pantene.

\section{METODE PENELITIAN}

\section{Jenis Penelitian}

Jenis penelitian yang dilakukan dalam penelitian ini adalah deskriptif kasual. Penelitian deskriptif kasual dilakukan untuk memperoleh gambaran tentang penelitian yang berkaitan dengan kepercayaan merek dan loyalitas pelanggan pada produk shampo merek Pantene.

\section{Metode Pengumpulan Data}

Dalam penelitian ini untuk mengumpulkan data diperlukan beberapa metode yaitu : Observasi, Studi Pustaka, Dokumentasi, Interview, dan Kuesioner.

\section{Populasi dan Tehnik Penarikan Sampel}

Populasi dalam penelitian ini yaitu mahasiswi yang menggunakan produk shampo merek Pantene di Fakultas Ekonomi Universitas Tadulako Palu. Jumlah populasi dalam penelitiana ini tidak diketahui secara pasti, dikarenakan tidak adanya data pendukung yang menunjukan data secara pasti konsumen produk shampo merek Pantene di Fakultas Ekonomi Universitas Tadulako Palu.

Teknik pengambilan sampel yang digunakan adalah metode Purposive Sampling, yaitu pengambilan sampel yang dipilih secara cermat dengan mengambil objek penelitian yang selektif dan mempunyai ciri-ciri yang spesifik. Karakteristik Sampel dalam penelitian ini adalah sebagai berikut: 1) Merupakan mahasiswi di Fakultas Ekonomi Universitas Tadulako Palu angkatan 2013 - 2016. 2) Mahasiswi yang telah menggunakan produk shampo merek Pantene dalam waktu > 3 bulan berturutturut.3) Bersedia mengisi kuesioner penelitian. Dengan demikian jumlah sampel penelitian ini sejumlah 96 orang responden yang memenuhi karakteristik sampel.

\section{Definisi Operasional Variabel Variabel indevenden}

Variabel independen dalam penelitian ini adalah kepercayaan merek (X) yang terdiri dari :

1. Karakteristik merek (X1)

a) Reputasi merek, b) Prekditabilitas merek, c) Kesadaran merek, dan d) Kompetensi merek.

2. Karakteristik perusahaan (X2)

a) Reputasi perusahaanMotivasi pelanggan yang diinginkan, b) Integritas perusahaan, dan c) Kepercayaan pada perusahaan.

3. Karakteristik konsumen dengan merek (X3)

a) Emosional konsumen dengan kesamaan merek, b) Kesukaan terhadap merek, dan c) Pengalaman terhadap merek. Variabel devenden

Variabel dependen di penelitian ini adalah loyalitas pelanggan. yaitu dengan indikator berikut ini :

1. Konsumen melakukan pembelian secara berulang-ulang pada produk.

2. Membeli di luar lini produk.

3. Merekomendasikan produk ke orang lain

4. Menunjukan kekebalan dari daya tarik pesaing atau tidak mudah terpengaruh oleh daya tarik produk sejenis dari pesaing. 


\section{Cahyaningtyas E.}

\section{Pengujian Instrumen Penelitian Uji Validitas}

Menurut Sugiyono (2014:93) bahwa syarat minimum untuk dianggap memenuhi syarat adalah $\mathrm{r}=$ 0,3 jadi, kolerasi antar buti dengan skor total $<0,3$ maka butir dalam instrumen tersebut dinyatakan tidak valid. Sebaliknya, jika total positif dan lebih besar dari $0,3(r \geq 0,3)$ maka instrumen tersebut dinyatakan valid.

\section{Uji Realibilitas}

Pengujian reliabilitas dilakukan dengan menggunakan Cronbach's Alpha. Koefisien Cronbach's Alpha yang > 0,60 menunjukkan kehandalan reliabilitas instrumen, bila dilakukan penelitian ulang dengan waktu dan dimensi yang berbeda akan menghasilkan kesimpulan yang sama. Dan jika koefisien Cronbach's Alpha yang $<0,60$ menunjukkan kurang handalnya instrumen, bila variabelvariabel tersebut dilakukan penelitian ulang dengan waktu dan dimensi yang berbeda akan menghasilkan kesimpulan yang berbeda. Selain itu, Cronbach's Alpha yang semakin mendekati 1 menunjukkan semakin tinggi konsistensi internal reliabilitasnya.

\section{Pengujian Asumsi Klasik Uji Normalitas}

. Pengujian normalitas dalam penelitian ini digunakan dengan melihat normal probability plot yang membandingkan distribusi kumulatif dari dari data sesungguhnya dengan distribusi kumulatif dari data normal.

\section{Uji Heterokedastistas}

Uji heterokedastisitas bertujuan untuk menguji apakah dalam model regresi terjadi ketidaksamaan varian dari satu pengamatan ke pengamatan yang lain. Ghozali (2006:117) mendefinisikan heterokedastisitas adalah salah satu asumsi klasik dalam analisis regresi linier berganda yang distribusi probabilitas ganguan dianggap tetap untuk seluruh nilai-nilai variabel bebas.

\section{Multikolinieritas} berikut:

Untuk mendeteksi ada atau tidaknya multikolinieritas di dalam model regresi adalah sebagai

1) Mempunyai angka Tolerance $\leq 0,1$ dan mempunyai nilai VIF (Variance Inflation Factor) $\geq 10$, maka terjadi multikolinieritas.

2) Mempunyai angka Tolerance $\geq 0,1$ dan mempunyai nilai VIF (Variance Inflation Factor) $\leq 10$, maka tidak terjadi multikolinieritas.

\section{Pengujian Hipotesis Pertama (Uji Simultan/Uji F)}

Untuk mengetahui signifikan atau tidak pengaruh secara bersama-sama variabel bebas terhadap variabel terikat maka digunakan probability sebesar $5 \%(\alpha=0,05)$. Yaitu dengan ketentuan sebagai berikut:

1. Jika sig $>\dot{\alpha}=(0,05)$, maka $\mathrm{H} 0$ diterima H1 ditolak.

2. Jika sig $<\dot{\alpha}=(0,05)$, maka H0 ditolak H1 diterima.

\section{Pengujian Hipotesis Kedua (Uji Parsial/Uji T)}

Pengujian ini untuk mengetahui pengaruh masing-masing variabel independen secara parsial berpengaruh positif dan signifikan terhadap variabel dependen di lakukan dengan pengujian Uji $t$, dimana derajat signifikan yang digunakan adalah $\alpha=0,05$ dengan bentuk pengujian sebagai berikut:

1. Jika nilai signifikan (sig. $\mathrm{t}$ ) $\leq \alpha=0,05$, artinya masing-masing variabel independen secara parsial berpengaruh signifikan terhadap loyalitas mahasiswi Fakultas Ekonomi Universitas Tadulako Palu membeli produk shampo produk Pantene. Dengan demikian dapat dinyatakan bahwa hipotesisi yang diajukan dalam penelitian ini masing-masing diterima secara parsial.

2. Jika nilai signifikan (sig. $t$ ) $\geq \alpha=0,05$, hal ini artinya masing-masing variabel independen secara parsial berpengaruh tidak signifikan terhadap loyalitas mahasisiwi Fakultas Ekonomi Universitas Tadulako Palu membeli produk shampo Pantene. Dengan demikian dapat dinyatakan bahwa hipotesisi yang diajukan dalam penelitian ini masing-masing ini ditolak secara parsial. 


\section{HASIL DAN PEMBAHASAN}

Hasil Uji Instrumen Penelitian Uji Validitas:

Tabel 2 Hasil Uji Validitas

\begin{tabular}{|c|c|c|c|c|}
\hline No & Variabel Penelitian & Indikator Penelitian & $\begin{array}{c}\text { Corrected } \\
\text { Item-Total } \\
\text { Correlation }\end{array}$ & Ket \\
\hline \multirow[t]{4}{*}{1} & \multirow{4}{*}{ Karakteristik Merek (X1) } & Reputasi Merek $\left(\mathrm{X}_{1.1}\right)$ & 0,585 & Valid \\
\hline & & Prekdibilitas Merek (X1.2) & 0,770 & Valid \\
\hline & & Kesadaran Merek (X1.3) & 0,626 & Valid \\
\hline & & Kompetensi Merek (X1.3) & 0.740 & Valid \\
\hline \multirow[t]{4}{*}{2} & \multirow{4}{*}{ Karakteristik Perusahaan (X2) } & Reputasi Perusahaan (X2.1) & 0,481 & Valid \\
\hline & & Motivasi Pelanggan (X2.2) & 0,543 & Valid \\
\hline & & Integritas Perusahaan (X2.3) & 0,595 & Valid \\
\hline & & Kepercayaan Perusahaan (X2.4) & 0.573 & Valid \\
\hline \multirow[t]{3}{*}{3} & \multirow{3}{*}{$\begin{array}{c}\text { Karakteristik Pelanggan } \\
\text { dengan Merek (X3) }\end{array}$} & Emosional Konsumen (X3.1) & 0,492 & Valid \\
\hline & & Kesukaan Merek (X3.2) & 0,618 & Valid \\
\hline & & Pengalaman Merek (X3.3) & 0,531 & Valid \\
\hline \multirow[t]{4}{*}{4} & \multirow{4}{*}{ Loyalitas Pelanggan $(\mathrm{Y})$} & Pembelian Ulang (Y1.1) & 0,603 & Valid \\
\hline & & Membeli di Luar Lini Produk (Y1.2) & 0,582 & Valid \\
\hline & & Merekomendasikan Produk (Y1.3) & 0,580 & Valid \\
\hline & & Kesetiaan Pada Produk (Y1.4) & 0,655 & Valid \\
\hline
\end{tabular}

Sumber: Diolah Kembali

Berdasarkan hasil uji validitas yang telah dilakukan, dari semua item peryataan untuk variabel karakteristik merek (X1), karakteristik perusahaan (X2), karakteristik pelanggan dengan merek (X3) dan loyalitas pelanggan (Y) dalam kuesioner yang digunakan dalam penelitian ini adalah valid.

\section{Uji Reliabilitas}

Tabel 3 Hasil Uji Reliabilitas

\begin{tabular}{|c|l|c|c|}
\hline No & \multicolumn{1}{|c|}{ Variabel Penelitian } & $\begin{array}{c}\text { Cronbach's } \\
\text { Alpha }\end{array}$ & Ket \\
\hline 1 & Karakteristik Merek $\left(\mathrm{X}_{1}\right)$ & 0,843 & Reliabel \\
\hline 2 & Karakteristik Perusahaan $\left(\mathrm{X}_{2}\right)$ & 0,751 & Reliabel \\
\hline 3 & Karakteristik Pelanggan dengan Merek $\left(\mathrm{X}_{3}\right)$ & 0,724 & Reliabel \\
\hline 4 & Loyalitas Pelanggan $(Y)$ & 0,794 & Reliabel \\
\hline
\end{tabular}

Sumber: Diolah Kembali

Berdasarkan Tabel 3 di atas, hasil uji reliabilitas dari semua variabel penelitian ini mempunyai koefisien Cronbach's Alpha $\geq 0,6$. Maka semua variabel dalam penelitian ini reliabel, sehingga dapat digunakan untuk mengukur variabel yang diteliti yaitu pengaruh kepercayaan merek terhadap loyalitas pelanggan membeli shampo Pantene studi pada mahasiswi Fakultas Ekonomi Universitas Tadulako Palu untuk keperluan pengujian hipotesis.

\section{Hasil Uji Asumsi Klasik \\ Hasil Uji Normalitas}

Berikut ini hasil uji normalitas data, yang akan ditunjukan pada Gambar 2 sebagai berikut: 


\section{Cahyaningtyas E.}

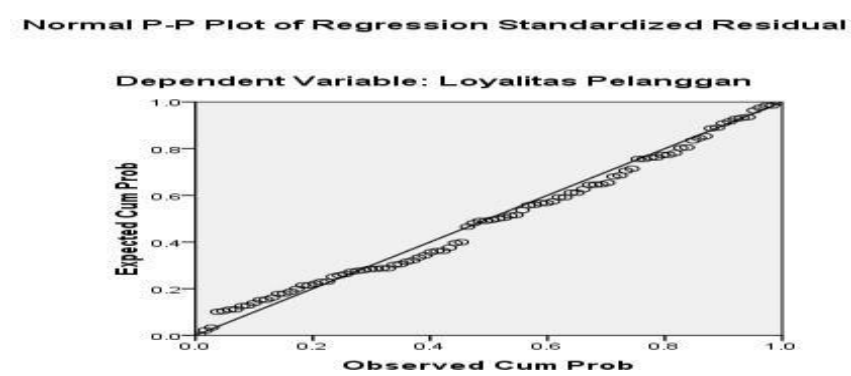

Gambar 2 Hasil Uji Normalitas

Dari Gambar 2 di atas menunjukan hasil pengujian data dengan bantuan komputer program statistik SPSS For Windows Release 16.0, bahwa data- data dari hasil penelitian ini cenderung tersebar mendekati atau sekitar garis diagonal dan mengikuti arah garis diagonal sehingga asumsi normalitas dapat dikatakan terpenuhi.

\section{Hasil Uji Heterodakedastisitas}

Berikut ini hasil pengujian dengan menggunakan analisis grafik dapat dilihat pada Gambar 5.6 di bawah ini:

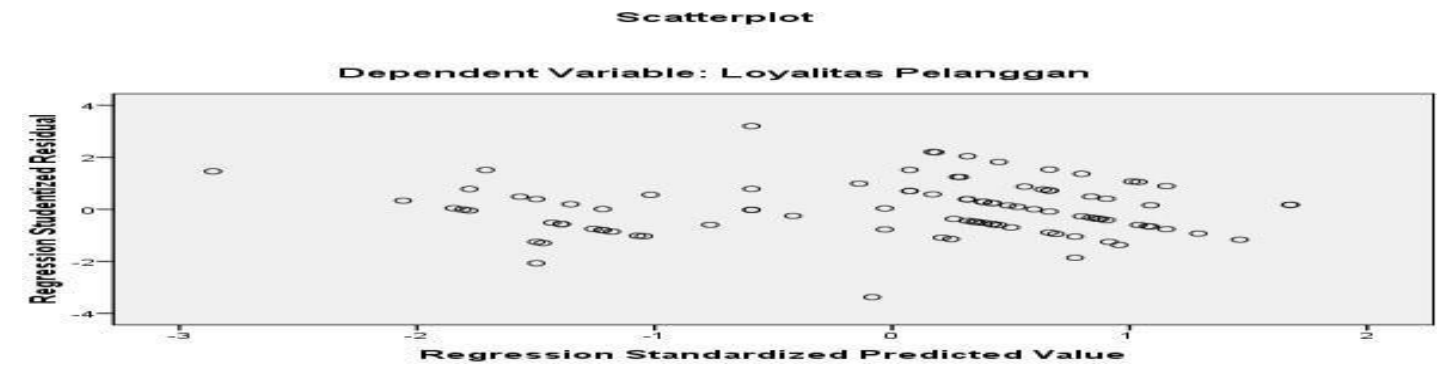

Gambar 3 Hasil Uji Heterokedastisitas

Dari Gambar 3 di atas bahwa tidak ada pola yang jelas, serta titik-titik menyebar di atas dan di bawah angka 0 pada sumbu Y, maka dapat disimpulkan pada model regresi tidak terjadi masalah heterokedastisitas. Sehingga model regresi layak dipakai untuk loyalitas pelanggan berdasarkan masukan variabel independen, yaitu kepercayaan merek $(\mathrm{X})$ yang terdiri dari karakteristik merek $\left(\mathrm{X}_{1}\right)$, karakteristik perusahaan $\left(\mathrm{X}_{2}\right)$ dan karakteristik pelanggan dengan merek $\left(\mathrm{X}_{3}\right)$.

\section{Hasil Uji Multikolianeritas}

Tabel 4 Hasil Pengujian Multikolinearitas

\begin{tabular}{|c|l|c|c|c|}
\hline \multirow{2}{*}{ No } & \multicolumn{1}{|c|}{ Variabel Bebas } & \multicolumn{2}{c|}{ Collinierity Statistik } & \multirow{2}{*}{ Ket } \\
\cline { 3 - 4 } & \multicolumn{1}{|c|}{ Tolerance } & VIF & \multirow{2}{*}{ Normal } \\
\hline 1 & Karakteristik Merek $\left(\mathrm{X}_{1}\right)$ & 0,549 & 1.822 & Normal \\
\hline 2 & Karakteristik Perusahaan $\left(\mathrm{X}_{2}\right)$ & 0,428 & 2.339 & Normal \\
\hline 3 & $\begin{array}{l}\text { Karakteristik Pelanggan dengan Merek } \\
\left(\mathrm{X}_{3}\right)\end{array}$ & 0,366 & 2.735 & \\
\hline
\end{tabular}

Sumber: Data Diolah Kembali

Hasil penelitian pada Tabel 4 di atas, bahwa nilai tolerance yang diperoleh $\leq 0,1$ dan nilai VIF $<$ 10. Dengan demikian dapat disimpulkan bahwa dalam penelitian ini tidak terjadi multikolinearitas.

\section{Analisi Regresi Linear Berganda} 5 berikut:

Hasil analisis menggunakan program SPSS For Windows Release 16.0, dapat dilihat pada Tabel 
Tabel 5 Hasil Perhitungan Regresi Linear Berganda

\begin{tabular}{|c|c|c|c|c|c|c|}
\hline \multirow{2}{*}{\multicolumn{2}{|c|}{ Variabel }} & \multicolumn{2}{|c|}{$\begin{array}{l}\text { Unstandardized } \\
\text { Coefficients (B) }\end{array}$} & \multirow{2}{*}{$\begin{array}{c}\begin{array}{c}\text { Standardized } \\
\text { Coefficients }\end{array} \\
\text { Beta }\end{array}$} & \multirow{2}{*}{$\mathbf{T}$} & \multirow{2}{*}{ Sig. } \\
\hline & & B & $\begin{array}{l}\text { Std. } \\
\text { Error }\end{array}$ & & & \\
\hline \multicolumn{2}{|l|}{ (Constant) } & .248 & .315 & & .786 & .763 \\
\hline \multicolumn{2}{|l|}{ Karakteristik Merek (X1) } & .288 & .084 & .288 & 3.429 & .001 \\
\hline \multicolumn{2}{|l|}{ Karakteristik Perusahaan (X2) } & .353 & .103 & .324 & 3.411 & .001 \\
\hline \multicolumn{2}{|l|}{ Karakteristik Pelanggan-Merek (X3) } & .299 & .102 & .300 & 2.919 & .004 \\
\hline R Square $\left(\mathrm{R}^{2}\right)$ & $=0.645$ & & F- hitung & $=55.648$ & & \\
\hline Adjusted R Square & $=0.633$ & & $\begin{array}{l}\text { Constant } \\
\text { a }\end{array}$ & $=0,248$ & & \\
\hline Multiple R & $=0.803$ & & Sig. F & $=0.000$ & & \\
\hline Jumlah data 95 Responden & & & & & & \\
\hline
\end{tabular}

\section{Sumber: Data Diolah Kembali}

Berdasarkan Tabel 5 hasil nilai koefisien kolerasi $\mathrm{R}$ adalah 0,803 . Nilai $\mathrm{R}$ berkisar antara 0 sampai 1, jika nilai koefisien kolerasi $\mathrm{R}$ mendekati 0, maka hubungan antara semakin lemah. Nilai kolerasi yang didapat dalam penelitian ini berdasarkan hasil regresi adalah 0,803 yang artinya hubungan atau korelasi antara variabel kepercayaan merek (X) yang terdiri dari karakteristik merek (X1), karakteristik perusahaan (X2) dan karakteristik pelanggan dengan merek (X3) terhadap loyalitas mahasiswi Fakultas Ekonomi Universitas Tadulako Palu sanggat kuat.

\section{Pengujian Hipotesis \\ Pengujian Hipotesis Pertama (Uji F)}

Tabel 6 Hasil Pengujian Simultan (Uji F)

ANOVA $^{\mathrm{b}}$

\begin{tabular}{|c|c|c|c|c|c|c|}
\hline \multirow{4}{*}{1} & Model & Sum of Squares & $D f$ & Mean Square & $F$ & Sig. \\
\hline & Regression & 16.323 & 3 & 5.441 & 55.648 & $.000^{\mathrm{a}}$ \\
\hline & Residual & 8.989 & 92 & .098 & & \\
\hline & Total & 25.312 & 95 & & & \\
\hline
\end{tabular}

Berdasarkan hasil uji regresi pada Tabel 6 di atas, diperoleh $F_{\text {hitung }}$ sebesar 55.648 dengan tingkat signifikansi $0,000<\alpha=0,05$, berdasarkan hasil tersebut dapat disimpulkan bahwa hipotesis yang pertama terbukti sebagai suatu kebenaran empiris (nyata) berdasarkan hasil uji penelitian. Maka dapat disimpulkan bahwa kepercayaan merek (X1) yang terdiri dari karakteristik merek (X1), karakteristik perusahaan (X2) dan karakteristik pelanggan dengan merek (X3), secara simultan berpengaruh signifikan terhadap variabel loyalitas mahasisiwi Fakultas Ekonomi Universitas Tadulako Palu membeli produk shampo Pantene .

\section{Pengujian Hipotesis Kedua (Uji T)}

Berdasarkan hasil pengujian yang diperoleh dalam penelitian, variabel karakteristik merek (X1) memiliki tingkat signifikansi t sig. $(0,001)<\alpha=(0,05)$. Hal ini menunjukan bahwa hipotesis kedua yang menyatakan karakteritik merek (X1) secara parsial berpengaruh positif dan signifikan terhadap loyalitas mahasiswi di Fakultas Ekonomi Universitas Tadulako Palu membeli produk shampo Pantene, dengan pengaruh sebesar $28,8 \%$. Maka dapat disimpulkan bahwa hipotesis kedua dapat diterima dan terbukti. 


\section{Pengujian Hipotesis Ke Tiga (Uji T)}

Hasil penelitian menunjukkan bahwa variabel karakteristik perusahaan (X2) memiliki tingkat signifikansi t sig. $(0,001)<\alpha=(0,05)$. Dengan demikian bahwa variabel karakteristik perusahaan(X2) dalam penelitian ini secara parsial berpengaruh positif dan signifikan terhadap loyalitas mahasiswi Fakultas Ekonomi Universitas Tadulako Palu membeli produk shampo Pantene, dengan pengaruh sebesar 33,4\%. Maka dapat disimpulkan bahwa hipotesis ketiga dapat diterima dan terbukti.

\section{Pengujian Hipotesis Ke empat (Uji T)}

Hasil penelitian menunjukkan bahwa variabel karakteristik pelanggan dengan merek (X3) memiliki tingkat signifikansi t sig. $(0,004)<\alpha=(0,05)$. Dengan demikian bahwa variabel karakteristik pelanggan dengan merek (X3) dalam penelitian ini secara parsial berpengaruh positif dan signifikan terhadap loyalitas mahasiswi Fakultas Ekonomi Universitas Tadulako Palu membeli produk shampo Pantene, dengan pengaruh sebesar 30\%. Maka dapat disimpulkan bahwa hipotesis keempat dapat diterima dan terbukti.

\section{Pembahasan Hasil Penelitian}

Pengaruh Variabel Karakteristik Merek (X1) Terhadap Loyalitas Pelanggan (Y) Membeli Produk Shampo Pantene Pada Mahasiswi di Fakultas Ekonomi Universitas Tadulako Palu.

Pada penelitian ini, hasil pengujian menunjukkan bahwa variabel karakteristik merek (X1) yang terdiri dari reputasi merek(X1.1). prekdibilitas merek (X1.2), kesadaran merek (X1.3) dan kompetensi merek (X1.4) memberikan pengaruh positif terhadap loyalitas mahasiswi Fakultas Ekonomi Universitas Tadulako Palu membeli produk shampo Pantene. Dengan demikian bahwa secara statistik variabel karakteristik merek (X1) berpengaruh positif dan signifikan terhadap variabel loyalitas mahasiswi Fakultas Ekonomi Universitas Tadulako Palu membeli produk shampo Pantene. Adapun indikator dari variabel karakteritisk merek yang memiliki nilai mean tertinggi yaitu kesadaran merek dengan nilai mean 4,36, yang dapat dipastikan merupakan salah satu faktor loyalitas mahasiswi Fakultas Ekonomi Universitas Tadulako Palu membeli produk shampo Pantene.

Pengaruh Variabel Karakteristik Perusahaan (X2) Terhadap Loyalitas Pelanggan (Y) Membeli Produk Shampo Pantene Pada Mahasiswi di Fakultas Ekonomi Universitas Tadulako Palu.

Dalam penelitian ini, hasil pengujian menunjukkan bahwa variabel karakteristik perusahaan (X2) yang terdiri dari reputasi perusahaan (X2.1), motivasi pelanggan (X2.2), integritas perusahaan (X2.3) dan kepercayaan pada perusahaan (X2.4) memberikan pengaruh positif terhadap loyalitas mahasiswi Fakultas Ekonomi Universitas Tadulako Palu membeli produk shampo Pantene. Dengan demikian bahwa secara statistik variabel karakteristik perusahaan (X2) berpengaruh positif dan signifikan terhadap variabel loyalitas mahasiswi Fakultas Ekonomi Universitas Tadulako Palu membeli produk shampo Pantene. Adapun indikator dari variabel karakteritisk perusahaan yang memiliki nilai mean tertinggi yaitu kepercayaan pada perusahaan dengan nilai mean 4,32, yang dapat dipastikan merupakan salah satu faktor loyalitas mahasiswi Fakultas Ekonomi Universitas Tadulako Palu membeli produk shampo Pantene.

\section{Pengaruh Variabel Karakteristik Pelanggan dengan Merek (X3) Terhadap Loyalitas Pelanggan (Y) Membeli Produk Shampo Pantene Pada Mahasiswi di Fakultas Ekonomi Universitas Tadulako Palu.}

Pada penelitian ini, hasil pengujian menunjukkan bahwa variabel karakteristik pelanggan dengan merek (X3) yang terdiri dari emosional konsumen dengan merek (X3.1), kesukaan terhadap merek (X3.2) dan pengalaman merek (X3.3) memberikan pengaruh positif dan signifikan terhadap loyalitas mahasiswi Fakultas Ekonomi Universitas Tadulako Palu membeli produk shampo Pantene. Dengan demikian bahwa secara statistik variabel karakteristik pelanggan dengan merek (X3) berpengaruh secara positif dan signifikan terhadap variabel loyalitas mahasiswi Fakultas Ekonomi Universitas Tadulako Palu membeli produk shampo Pantene Adapun indikator dari variabel karakteritisk pelanggan dengan merek yang memiliki nilai mean tertinggi yaitu pengalaman merek dengan nilai mean 4,33, yang dapat dipastikan merupakan salah satu faktor loyalitas mahasiswi Fakultas Ekonomi Universitas Tadulako Palu membeli produk shampo Pantene. 


\section{KESIMPULAN DAN SARAN}

\section{Kesimpulan}

Berdasarkan hasil data yang telah diuraikan di atas dari hasil penelitian yang dilakukan di Fakultas

Ekonomi Universitas Tadulako, maka dapat ditarik kesimpulan sebagai berikut:

1. Kepercayaan merek yang terdiri dari karakteristik merek, karakteristik perusahaan dan karakteristik pelanggan dengan merek secara simultan berpengaruh positif dan signifikan terhadap loyalitas mahasiswi Fakultas Ekonomi Universitas Tadulako Palu membeli produk shampo Pantene.

2. Variabel karakteristik merek secara parsial berpengaruh positif dan signifikan terhadap loyalitas mahasiswi Fakultas Ekonomi Universitas Tadulako Palu membeli produk shampo Pantene.

3. Variabel karakteristik perusahaan secara parsial berpengaruh positif dan signifikan terhadap loyalitas mahasiswi Fakultas Ekonomi Universitas Tadulako Palu membeli produk shampo Pantene.

4. Variabel karakteristik pelanggan dengan merek secara parsial berpengaruh positif dan signifikan terhadap loyalitas mahasiswi Fakultas Ekonomi Universitas Tadulako Palu membeli produk shampo Pantene.

\section{Saran}

Berdasarkan uraian hasil penelitian dan kesimpulan, maka ada beberapa hal yang direkomendasikan kepada pihak terkait dengan penelitian ini sebagai berikut :

1. Dari hasil penelitian yang penulis lakukan bahwa pengaruh kepercayaan merek terhadap loyalitas pelanggan yang memiliki nilai koefisien kolerasi sangat kuat, hal ini berpeluang bagi perusahaan $P \& G$ untuk lebih meningkatkan pengembangan dari karakteristik merek, karakteristik perusahaan dan karakteristik pelanggan dengan merek, berdasarkan kebutuhan dan keinginan pelanggan untuk terciptanya kepuasan pelanggan yang berpengaruh pada peningkatan loyalitas pelanggan.

2. Diharapkan kepada pihak perusahaan $P \& G$ yang melakukan pemasaran untuk mengevaluasi keinginan pelanggan dalam melakukan inovasi, dengan mengeluarkan produk baru agar dapat memenuhi keinginan dan kebutuhan pelanggan yang selalu berubah-ubah dan mampu bersaing di pasaran. Perusahaan juga perlu menjaga hubungan baik dengan pelanggan, dengan cara selalu menjaga reputasi dan integritas perusahaan.

3. Bagi peneliti selanjutnya yang ingin menjadikan sebagai referensi dapat menambah dan mengkombinasikan variabel-variabel yang mempengaruhi loyalitas pelanggan membeli produk shampo Pantene, agar hasil yang didapatkan lebih maksimal dan memberikan kontribusi bagi pihak yang berkepentingan.

\section{REFERENSI}

Adisaputro, Gunawan, 2010. Manajemen Pemasaran. Edisi Pertama, Penerbit Sekolah Tinggi Ilmu Manjemen YKPN, Yogyakarta.

Candra Yuni, 2008. Pengaruh bauran pemasaran dan keterlibatan keluarga terhadap Air Minum Aqua. Jurnal of Marketing Management, Vol. 13, No.4, 2008.

Delgado, 2003. Development and Validation of a Brand Trush Scale International . Journal of Market Research, Vol. 45 No.1,PP 35-34.

Ghozali, Imam, 2006. Aplikasi Analisis Multivariate dengan Program SPSS. Penerbit Badan Universitas Diponegoro, Semarang.

Kotler, Philip dan Keller, 2009. Manajemen Pemasaran. Edisi Ketiga Belas Jilid I, Terjemahan Bob Sabran, Penerbit PT. Erlangga, Jakarta.

Lau, G.T. dan Lee, S.H, 1999. Customer Trust In A Brand the Link To Brand Loyalty. Journal Of Market Focused Manajement.

Riana Gede, 2012 .Pengaruh Trust In A Brand Terhadap Loyalitas Pada Konsumen keputusan pembelian leasing sepeda motor suzuki di kabupaten pesisir selatan”. Jurnal Buletin Studi Ekonomi, Vol. 14, No.2.

Simamora, Bilson, 2007. Panduan Riset Perilaku Konsumen. Penerbit Pustaka Utama, Surabaya. 


\section{Cahyaningtyas E.}

Sumarni Murti dan Soeprihanto, 2010. Pengantar Bisnis (Dasar-Dasar Ekonomi Perusahaan). Edisi kelima, Liberty, Yogyakarta.

Sumarwan, 2004. Teori dan penerapan dalam pemasaran Perilaku Konsumen, Penerbit Ghalia Indonesia, Bogor.

Surya dan Setiyaningrum, 2009. Analisis Persepsi Konsumen pada Aplikasi Bauran Pemasaran Serta Hubungannya terhadap Loyalitas Konsumen (Studi kasus pada Hypermart Cabang kelapa Gading). Journal of Business Strategy and Execution 2, Vol. 18, No. 3.

Tjiptono, Fandy, 2008. Strategi Pemasaran. Edisi ketiga, Penerbit Andi, Yogyakarta.

\section{Sumber lain:}

Top Brand Index Produk Shampo Tahun 2013 - 2016. Diakses dari http://www.topbrandward.com. Pada tanggal 18 Agustus 2016, 19:34 WITA. 